\title{
How special is the Special and Differential Treatment under the SCM Agreement? A legal and normative analysis of WTO subsidy disciplines on developing countries
}

\author{
DOMINIC COPPENS * \\ Sidley Austin LLP (Geneva)
}

\section{Introduction}

The WTO Agreement on Subsidies and Countervailing Measures (SCM Agreement) firmly strengthened the disciplines on subsidies affecting trade in goods. Yet, the birth of this multilateral agreement in 1995 elicited a vivid discussion on whether it overly confines developing countries' policy space to employ subsidies as a development tool. The 2006 UNCTAD Trade and Development Report for instance concluded that it impinges directly on national rulemaking authority'. ${ }^{1}$ WTO Director-General Lamy firmly responded to what he called an accusation:

The alternative, it seems, would be to have no subsidy disciplines, which raises an intriguing question. Do we want to argue that the best contribution the WTO can make to development is to ensure that developing countries have no obligations in this area? Or that export subsidies should be allowed? ${ }^{2}$

Aiming to address this intriguing question, this contribution starts with an overview of the predecessors of the SCM Agreement and continues with an indepth legal analysis of the exact 'Special and Differential' (S\&D) treatment delineated for developing countries. ${ }^{3}$ In a final section, insights of economic research are integrated in order to normatively assess the existing regulatory framework: Is this the best contribution that the WTO can make to development?

\footnotetext{
*Email: dcoppens@sidley.com

The author is Associate at Sidley Austin LLP (Geneva). The views expressed in this paper do not represent the views of Sidley Austin LLP or its clients. The author wishes to thank Andreas Lendle, Simon Schropp, and the editor and two anonymous reviewers of World Trade Review for helpful suggestions.

1 UNCTAD, Trade and Development Report, 2006-Global Partnership and National Policies for Development (New York: United Nations Publications, 2006), 237 pp., at 169.

2 WTO, Lamy Calls for Debate on 'Flexibility' and What Makes Good 'Policy Space' (27 September 2006).

3 S\&D treatment under the Agreement on Agriculture is not addressed.
} 


\section{Historical context}

In search for multilateral disciplines preventing devastating beggar-thy-neighbor reflexes, the US introduced in the mid 1940s the text which served as the basis for the negotiations on an International Trade Organization (ITO). In its Suggested Charter, drafted in close consultation with the UK, it proposed to phase-out export subsidies $^{4}$ and to introduce procedural disciplines on all trade distorting subsidies, but did not stipulate any S\&D treatment. ${ }^{5}$ In discussing its proposed disciplines on tariff bindings with developing countries, the US delegate had nonetheless emphasized the relevance of subsidies as policy instruments, but considered that sufficient policy space would remain in place:

These countries, deeply concerned with the problem of industrialization and full employment, want to use restrictive measures to protect their infant industries. In general, they remain unimpressed with our contention that subsidies offer the least objectionable method for this purpose. They point out that, while tariffs and subsidies both amount to charges on their economies, the very real difficulties in raising the revenue to pay subsidies make the latter impractical for them. ${ }^{6}$

This quote illustrates that, since the very beginning of the multilateral trade regime, participants very well understood some fundamentals of basic trade economics. First of all, if production is too low because of a domestic market failure, a production subsidy is superior to a tariff as corrective instrument since the latter also negatively affects consumers in the domestic market. This theoretical argument also found empirical support in the second half of the twentieth century in the superior performance of outward-oriented, 'export-promotion' strategies (adopted in particular by East Asian countries) over inward-oriented, 'importsubstitution' strategies (often adopted by Latin American countries). ${ }^{7}$ Moreover, the argument that developing countries would de facto not be able to use their policy space for subsidization suggests that they would have an interest that more

4 An exception related to agricultural export subsidies was inscribed.

5 The US rejected the infant industry argument on classic grounds (i.e., inefficient local production) and S\&D treatment did not serve its export interests. See R. E. Hudec, Developing Countries in the GATT Legal System (Aldershot: Gower, 1987), 259 pp., at 9-10.

6 As cited in D. Irwin, P. C. Mavroidis, and A. O. Sykes, The Genesis of the GATT (Cambridge: Cambridge University Press, 2008), at 76, 104-105. See also London Draft (E/PC/T/33), at 8, 16, 17, 32.

7 The contribution of selective (export) subsidies in such export-promotion strategy remains debated. In theory, an export subsidy is equally not an optimal instrument to correct domestic market failures as it, like tariffs, negatively affects domestic consumption but a recent World Bank study stressed that selective interventions spurring export diversification could be useful for low-income countries (see also below). See J. N. Bhagwati, 'Export-Promoting Trade Strategy, Issues and Evidence', 3:1 World Bank Research Observer (January, 1988), 27-57; World Bank, The East Asian Miracle: Economic Growth and Public Policy (Oxford: Oxford University Press, 1993), 389 pp.; Commission on Growth and Development, The Growth Report-Strategies for Sustained Growth and Inclusive Development (Washington, DC: The World Bank, 2008), 190 pp.; R. Newfarmer, W. Shaw, and P. Walkenhorst (eds.), Breaking into New Markets-Emerging Lessons for Export Diversification (Washington, DC: The World Bank, 2009), $265 \mathrm{pp}$. 
developed countries are constrained in their leeway to offer subsidies as they can never win a 'subsidy war' in export competing sectors.

At the end of the ITO negotiations, the Havana Charter disciplined subsidies largely along the same lines as initially suggested by the US and UK but this Charter was never implemented, implying that only the General Agreement on Tariffs and Trade (GATT) came into force. Because the principle prohibition of export subsidies was not transposed to the GATT, this agreement did not contain any substantive discipline on subsidies. ${ }^{8}$ Observe that the absence of more flexibility for developing countries on subsidies under the Havana Charter reflected the general victory of the US in limiting S\&D treatment. But this initial and unimplemented US victory dissolved when the first effective substantive disciplines were drafted over the next decades. ${ }^{9}$

Since the GATT did not prevent destructive subsidy competition for penetrating export markets, ${ }^{10}$ negotiations on substantive disciplines on export subsidies were launched already in the 1950s, finally resulting in a non-exhaustive list of prohibited export subsidies on non-primary products (the 1960 Declaration juncto Article XVI:B of the GATT). Developing countries (except for Zimbabwe) were however unwilling to adopt the 1960 Declaration, because of the more flexible treatment of primary products and their wish to preserve policy space. ${ }^{11,12}$

A further step in disciplining subsidies was made in the Tokyo Round Subsidies Code (1979), which was a plurilateral agreement (only accepted by 24 countries) that entered into force in 1980. It resulted from a compromise between the US, aiming at more stringent subsidy disciplines to block the revival of 'competitive subsidization' ${ }^{13}$ and other GATT Contracting Parties, aiming at more stringent disciplines on unilateral countervailing duties (CVDs) on 'subsidized' imports. Next to strengthening disciplines on CVDs, this code prohibited export subsidies on non-primary goods (including a non-exhaustive list that built on the 1960 Declaration) and introduced rather flexible substantive disciplines on domestic subsidies. Raising the infant-industry argument and threatening to refrain from signing the code, ${ }^{14}$ developing countries successfully negotiated to be 'virtually' excused from all new subsidy disciplines, which was clearly 'a defeat'

8 See Hudec, above n. 5 , at 23.

9 The US stance was weakened by its own persistent demand for more flexibility in the field of agriculture. See Hudec, above n. 5, at 15-16.

10 The multilateral non-violation complaint (XXIII(b) of the GATT) and unilateral CVDs are ineffective to protect exporters' interests in third markets.

$11 \mathrm{~J}$. H. Jackson, World Trade and the Law of GATT-A Legal Analysis of the General Agreement on Tariffs and Trade (Indianapolis: The Bobbs-Merrill Company, 1969), at 399.

12 For a list of 17 signatories, see MTN.GNG/NG10/W/4, 28 April 1987, at 75.

13 GATT Director-General as cited in T. P. Stewart (ed.), The GATT Uruguay Round-A Negotiating History (1986-1992) - Volume 1 (Deventer: Kluwer, 1993), 1,382 pp., at 815.

14 Export subsidies were also seen as means of offsetting other distortions (e.g., overvalued exchange rate, high tariffs on imported capital goods). 
for the US. ${ }^{15}$ Attempting to strengthen their export subsidy obligations, the US however refrained from offering Subsidies Code treatment to developing countries that did not enter into a commitment to reduce export subsidies. ${ }^{16}$ Developing countries (as well as the EC) firmly and correctly objected the legality of this position, ${ }^{17,18}$ which complicated and in some instances even prevented their accession to the Subsidies Code. ${ }^{19}$ This discussion shows the growing unease on the part of the US on what it called 'unfair' competition from producers of developing countries as they steadily gained market share in previously US dominated sectors.

L'bistoire se répète in the 1980s: competitive subsidization in response to an economic downturn, ${ }^{20}$ a multilateral framework still unable to halt this subsidy and CVD reflex, and negotiations in a new trade round, the Uruguay Round (1986-1994), with a similar agenda among participants; the US continued its 'antisubsidy' crusade whereas the others, including developing countries, advocated more stringent rules on CVDs. But the outcome with regard to developing countries was substantially dissimilar. Indeed, the strengthening of subsidy disciplines on developing countries was one of the novelties of the multilateral SCM Agreement, binding on all WTO Members. Article 27 of this agreement elaborates S\&D treatment and, as if it were a preamble, still declares that 'Members recognize that subsidies may play an important role in economic development programmes of developing countries', but it will be analysed in the next sections whether the agreement indeed leaves sufficient policy space to this end. ${ }^{21}$ In the Doha Round launched in 2001, developing countries have introduced a number of proposals to reintroduce more flexibility, though these have been highly contested. ${ }^{22}$ Given the deadlock in the negotiations, several unresolved aspects on S\&D treatment might have to be solved by the case law.

\section{Legal analysis}

\subsection{Introduction: scope and disciplines of the SCM Agreement}

Only measures that qualify as specific subsidies within the meaning of Articles 1 and 2 of the SCM Agreement are disciplined under this agreement and could be

15 They failed to obtain S\&D treatment regarding CVD action by other countries.

16 See SCM/M/3, 27 June 1980, at 3-9; SCM/W/116, 5 September 1986; MTN.GNG/NG10/W/4, 28 April 1987, at 87-93; Hudec, above n. 5, at 88-89.

17 See SCM/M/3, 27 June 1980, at 5-10.

18 See Hudec, above n. 5, at 83-84, 89, referring to L/4905, 3 December 1979; L/3149, 29 November 1968.

19 See, for example, SCM/M/19, 21 February 1984, at 9-11; SCM/M/3, 27 June 1980.

20 See Leutwiler Report: A. Dunkel, Trade Policies for a Better Future-The 'Leutwiler Report', the GATT and the Uruguay Round (Dordrecht: Martinus Nijhoff Publishers, 1987), 174 pp., at 46.

21 Article 27.1; see also Panel Report, Brazil-Aircraft (Article 21.5-Canada) (WT/DS46/RW, adopted 4 August 2000), footnote 49.

22 The latest draft text: TN/RL/W/236, 19 December 2008. An overview of the latest state of negotiations: TN/RL/W/254, 21 April 2011. 
vulnerable to CVD action by other WTO Members. A subsidy is present within the meaning of Article 1 when a government, ${ }^{23}$ either directly or indirectly through a private body, provides a financial contribution ${ }^{24}$ which confers a benefit. ${ }^{25}$ According to the case law, a benefit is present when the contribution is offered at better than market terms to the recipient. Such a subsidy has to be 'specific' to an industry or group of industries within the meaning of Article 2.

Once a specific subsidy has been found, the substantive disciplines of the SCM Agreement kick in. If this subsidy is contingent upon exportation or local content, it is in principle flatly prohibited by virtue of Article $3 .{ }^{26}$ Against all other specific subsidies, an 'actionable subsidy' claim could be formulated if it could be demonstrated that there are adverse effects (Article 5). ${ }^{27}$ Instead of challenging such specific subsidies before the WTO dispute settlement bodies, a WTO Member is equally allowed to impose CVDs to offset the injury on the domestic market if the disciplines set out in part V of the SCM Agreement are adhered to. In the next sections, we explore the extra flexibility given to developing countries regarding these subsidy and CVD disciplines.

\subsection{Special and differential treatment on probibited subsidies}

\subsubsection{Export subsidies}

Annex VII developing countries: least-developed countries and low-income countries listed in Annex VII(b). Article 3.1(a) of the SCM Agreement spells out a principle prohibition on export subsidies. By virtue of Article 27.2(a) juncto Annex VII of the SCM Agreement, this prohibition does not apply for two groups of developing countries (Annex VII developing countries): (a) least-developed countries (LDCs) designated as such by the United Nations (UN);28 and (b) other low-income countries listed in Annex VII(b) until their gross national income (GNI) per capita has reached \$1,000 per annum (Annex VII(b) countries). ${ }^{29}$ The Doha Ministerial Conference decided to raise this threshold to $\$ 1,000$ in constant 1990 dollars for three consecutive years. ${ }^{30}$ But not all developing countries below this threshold benefit from this S\&D treatment since this is confined to those explicitly listed in Annex VII(b). All original WTO Members at the time of conclusion of the Uruguay

23 Article 1.1(a)(1).

24 Or any form of income or price support in the sense of Article XVI of the GATT. Article 1.1(a)(2).

25 Article 1.1(b).

26 These subsidies are deemed to be specific by virtue of Article 2.3, and, therefore, do not have to pass the specificity test.

27 The effect on consumer welfare is not relevant for this analysis. See, for instance, Panel Report, EC-Large Civil Aircraft (WT/DS316/R, adopted 1 June 2011), para. 1.1991.

28 Annex VII(a) of the SCM Agreement.

29 On the use of GNI instead of GNP, see G/SCM/110/Add.8, 16 June 2011.

30 Moreover, countries will be re-included when their GNI per capita falls again below $\$ 1,000$. See WT/MIN(01)/17, 14 November 2001, paras. 10.1 and 10.4 . 
Round with per capita income below the $\$ 1,000$ were listed. ${ }^{31}$ On the other hand, none of the acceding countries was superadded afterwards. For instance, Vietnam, to its own surprise during the negotiations, could not benefit from this S\&D treatment even though its GNI per capita was below the threshold. ${ }^{32}$ Another implication of the closed list seems to be that LDCs (Annex VII(a)) will not continue to benefit from this exemption in case they graduate from this status on the basis of the UN definition and their GNI per capita is still be below the $\$ 1,000$ threshold. Although some developing countries have suggested otherwise, ${ }^{33}$ it would require a highly 'judicial active' Panel or Appellate Body to overturn the plain text of Annex VII as it only stipulates this threshold for those countries listed under paragraph (b). ${ }^{34}$

Annex VII(b) countries benefit from the export subsidy exemption until their GNI per capita reaches $\$ 1,000$ in constant 1990 dollars for three consecutive years, as reflected in the most recent available data. ${ }^{35}$ Until present, only five of them have graduated: Dominican Republic, Egypt, Guatemala, Morocco, and Philippines. ${ }^{36}$ All other listed countries (e.g., India, Indonesia) and current $\mathrm{LDCs}^{37}$ are thus still exempted from the prohibition on export subsidies. As further explained below, two caveats are, however, in place: (i) this exemption extinguishes for products that have reached export competiveness, and (ii) export subsidies are vulnerable to an actionable subsidy claim or CVD action.

Small trading developing countries. All developing countries that were not covered under Annex VII were given eight years to phase out their export subsidies (2003), but could request an extension by the SCM Committee in light of their development needs under Article 27.4. The SCM Committee had to annually review the necessity thereof. If a negative determination was made, the export subsidy had to be phased out within two years from the end of the last authorized period. ${ }^{38}$ A major disadvantage of this system was that the year-to-year extensions generated large uncertainty to governments and their business communities. ${ }^{39}$ Here again, the Doha Ministerial Conference provided some more flexibility, without

31 With the omission of Honduras, which was added by a technical rectification (WT/L/384, 19 December 2000; WT/GC/M/62, 28 February 2001).

32 For a list of other non-original WTO Members with GNI per capita of less than $\$ 1,000$ in 1990 dollars in 2009, see S. Creskoff and P. Walkenhorst, 'Implications of WTO Disciplines for Special Economic Zones in Developing Countries', World Bank Policy Research Working Paper (2009), 42 pp., at 24.

33 See TN/RL/GEN/177/Rev.2, 18 March 2011, para. 2.

34 The Doha Declaration (para. 10.1) also explicitly referred to Annex VII(b) countries.

35 The methodology for making this calculation is spelled out in G/SCM/38, 26 October 2003.

36 See G/SCM/110/Add 9, 20 June 2012.

37 Also LDCs that are non-original WTO Members benefit from this exception because Annex VII(a) is not a closed list.

38 Article 27.4.

39 See R. A. Torres, 'Free Zones and the World Trade Organization Agreement on Subsidies and Countervailing Measures', 2:5 Global Trade and Customs Journal (2007), 217-223, at 221. 
however extending the eight-year period in general. Only certain small trading developing countries were granted extensions for those export subsidy programmes in force in 2001 that provided full or partial exemptions from import duties and internal taxes. ${ }^{40}$ The level of subsidies benefiting from this transitional period could not be raised (standstill obligation). ${ }^{41}$ Until the end of 2013, the SCM Committee shall continue these authorizations subject only to an annual review of the transparency and standstill requirements. ${ }^{42}$ Consequently, their remaining export subsidies should be phased out no later than 31 December 2015.

Hence, this transitional flexibility to grant export subsidies currently merely applies to certain small trading developing countries and only with respect to their listed programmes. These relate to exemptions from import duties and internal taxes, which are often implemented in export processing zones (EPZs). ${ }^{43}$ Surely, this flexibility is relevant because such programmes mostly exempt firms located in EPZs from direct taxes and import duties on capital inputs. These measures go beyond the scope for such exemptions that would be allowed by virtue of footnote 1 of the SCM Agreement juncto the Illustrative List (items (e) and (i)). Yet, the same two caveats as with regard to Annex VII developing countries apply: extinction in case of export competitiveness and the possibility for actionable subsidy claims or CVD responses.

Before going into the first caveat, it has to be assessed whether Annex VII(b) countries could still benefit from the S\&D treatment under Article 27.4 in case they graduate. In a recent proposal, a number of Annex VII(b) countries sought to 'clarify' that this flexibility would indeed still be available. ${ }^{44}$ In their view, Article 27.2(b) lacks clarity as regards its application to Annex VII countries because it explicitly refers to 'the entry into force of the WTO Agreement' as kick off point for the eight-year phase-out period, which cannot be applied to graduated Annex VII countries as they only join this paragraph (b) at a later moment of time. ${ }^{45}$ In their reading, the eight-year phase-out period would therefore start at the moment of graduation and export subsidies would then become subject to the standstill obligation and 'development needs' test. ${ }^{46}$ Although the text is

40 G/SCM/39, 20 November 2001.

41 Article 27.4. See Panel Report, Brazil-Aircraft, paras. 7.58-7.67.

42 See WT/L/691, 31 July 2007.

43 See also Creskoff and Walkenhorst, above n. 32, at 23; Torres, above n. 39, at 221-222.

44 See TN/RL/GEN/177/Rev.2, 18 March 2011.

45 Article 27.2 reads:

The prohibition of paragraph 1 (a) of Article 3 shall not apply to:

(a) developing country Members referred to in Annex VII.

(b) other developing country Members for a period of eight years from the date of entry into force of the WTO Agreement, subject to compliance with the provisions in paragraph 4. [emphasis added]

46 They also hold that they could benefit from the possibility of further extensions pursuant to Article 27.4. 
indeed far from clear, it seems more plausible that, as argued by some other WTO Members, ${ }^{47}$ this proposal would be an amendment rather than a clarification. Indeed, it seems that S\&D treatment under Article 27.4 is only applicable to those Annex VII countries that have explicitly preserved their right to benefit from the extension offered at Doha. After all, there is no textual basis whatsoever to start the eight-year phase-out period only at the moment of graduation. In contrast, 'the entry into force of the WTO Agreement' could have been relevant as the starting point to graduated Annex VII(b) countries in those situations where they graduated before 2003. Moreover, the phase-out period under Article 27.4 was only extended for some limited programs of small-trading countries that had requested such an extension in 2001. Four low-income countries listed under Annex VII(b) (i.e., Bolivia, Honduras, Kenya, and Sri Lanka) ${ }^{48}$ have explicitly preserved their right to similarly benefit from this transitional S\&D treatment in case they would graduate, illustrating that they understood that such a request was needed. ${ }^{49}$ Under this reading, only those four countries will benefit from the limited S\&D treatment under Article 27.4 (e.g., standstill) in case they graduate before 2015. In contrast, all other Annex VII(b) countries, including those five countries that have so far graduated under Annex VII(b), non-original developing countries that acceded after the Doha Ministerial Conference $(2001)^{50}$, and graduated LDCs would not benefit from this transitional flexibility.

Export competitiveness. The flexibility to offer export subsidies for both groups of developing countries extinguishes for products that have reached export competitiveness. In that case, those export subsidies offered by Annex VII developing countries have to be phased out within eight years. ${ }^{51}$ With regard to small trading developing countries, they even have to be phased within two years.

According to Article 27.6, export competitiveness in a product exists if a developing country Member's exports of that product have reached a share of at least $3.25 \%$ in world trade of that product for two consecutive calendar years'. The focus is therefore on the country's share in trade, not on its share in total production. ${ }^{52}$ Yet, such export competitiveness is only established, and the extinction period thus only kicks off, if this is either (a) notified by the developing country Member itself or (b) computed by the WTO Secretariat at the request of any

47 TN/RL/W/254, 21 April 2011, para. 34.

48 See G/SCM/N/74/BOL \& Suppl.1, G/SCM/N/74/HND, G/SCM/N/74/KEN, and G/SCM/N/74/ LKA.

49 See WT/L/691, 31 July 2007, para. 4.

50 Again, other WTO Members explained this to Vietnam during accession negotiations (WT/ACC/ VNM/29, 30 October 2003).

51 Article 27.5.

52 Hence, it excludes production for domestic consumption. See Panel Report, US-Upland Cotton (WT/DS267/R, adopted 21 March 2005), para. 7.1441. 
other Member. ${ }^{53}$ The determination therefore de facto depends upon other Members' requests to the WTO Secretariat. With regard to Annex VII developing countries, only two such requests have been formulated so far, both made by the US (2003, 2010) regarding India's export competitiveness on textile and apparel exports. 54

These computations revealed two ambiguities in the interpretation of Article 27.6. First, does the concept of 'world trade' include trade between countries of the EU (i.e., intra-EU(27) trade)? Because Article 27.6 contains 'no guidance' on this issue, the WTO Secretariat made calculations on the basis of excluding as well as including intra-EU(27) trade. Obviously, the required share in world trade is less easily met in case intra-EU trade is included, and developing countries thus support calculations made on this basis. ${ }^{55}$ This view should be endorsed because the ordinary meaning of 'world trade' does not exclude trade between countries belonging to a customs union. This interpretation equally preserves the recognized 'important role' of subsidies for developing countries (Article 27.1), which would be undermined if a developing country could, without increasing its own share in world exports, reach export competitiveness on the basis of the formation or extension of a customs union.

Second, the text of Article 27.6 is also ambiguous on whether products should be defined at either the section or heading level of the Harmonized System (HS) Nomenclature. The US therefore requested that the computation was undertaken at both the section (i.e., 'Textiles and Textile Articles') and heading levels. ${ }^{56}$ The uncertainty flows from the definition of a 'product' in Article 27.6 as this refers to 'a section heading' of the HS Nomenclature, though the HS itself only contains 'sections' (group of chapters) or 'headings' (four-digit tariff level). ${ }^{57}$ Because they will more likely reach export competitiveness in a product defined at heading level, ${ }^{58}$ developing countries have pleaded for a definition at the section level but no consensus has so far emerged in the SCM Committee. On the basis of contacts with participating delegates in the Uruguay Round, Hoda and Ahuja reveal that negotiators had in mind 'sections' and not 'headings' ${ }^{59}$ Moreover, they doubt whether it is feasible to operate and dismantle an export promotion scheme on a

53 Article 27.6 of the SCM Agreement. The Secretariat only makes calculations according to the request of the WTO Member and does not interpret the results.

54 See G/SCM/132/Add.1, 23 March 2010; G/SCM/103/Add.1, 12 March 2003.

55 See, for example, G/SCM/W/443, 17 May 2001, at 2.

56 No request at the section level was made in the 2003 calculations.

57 The HS classification consists of 21 'sections', subdivided into 98 'chapters', and further subdivided into four-digit 'headings' and six-digit 'HS codes'. Tariff lines are defined at the six-digit level (or at further subdivisions).

58 See also Creskoff and Walkenhorst, above n. 32, footnote 56.

59 A. Hoda and R. Ahuja, 'Agreement on Subsidies and Countervailing Measures: Need for Clarification and Improvement', 39:6 Journal of World Trade 1009 (2005), 1009-1969, at 1028. See also G/SCM/W/443, 17 May 2001. 
four-digit heading level. ${ }^{60}$ On the other hand, the authentic French and Spanish texts refer to 'positions' and 'partidas' respectively, which correspond to four-digit 'headings' instead of 'sections'. At first sight, the rules of treaty interpretation (Article 33(3) of the Vienna Convention) might thus rather point to products defined at the four-digit heading level because this seems the only 'simultaneous' ordinary meaning as used in each authentic language. ${ }^{61}$ But it might be doubted whether the ordinary meaning of 'a section heading' in English could indeed refer to a 'heading' in HS Nomenclature parlance. ${ }^{62}$ In contrast to the other texts, the English text rather refers to 'a section' under the HS nomenclature. Given this ambiguity, recourse to preparatory work should be taken (Article 32 of the Vienna Convention), which leads back to the interpretation of a product at the section level as this was the drafters' intention. ${ }^{63}$

Turning to the 2010 calculations made by the WTO Secretariat, India's export competitiveness was found not only on a large number of textile and apparel products at the heading level, but also at the section level as it reached the share of $3.25 \%$ in world trade for two consecutive calendar years at the end of $2006 .{ }^{64}$ If the section level is appropriate to define a 'product', India will have to gradually phase out its export subsidies on all textiles and textile articles over a period of eight years. This result illustrates the downside, from a developing country's perspective, of defining products at the section level as it implies that all export subsidies on products under the broad section level will have to be phased out once such export competitiveness has been reached. ${ }^{65}$ Despite insistence of the US, India however tactically refuses to start phasing out any export subsidies as long as the above-mentioned interpretative difficulties are not resolved. ${ }^{66,67}$

Next to this lack of clarity, some developing countries have pointed to two fundamental flaws in the current definition of export competitiveness. ${ }^{68}$ First, the two-year period is considered too short to neutralize increased market shares simply resulting from short-term fluctuations in the market. ${ }^{69}$ This should be

60 Hoda and Ahuja, above n. 59, at 1028.

61 Appellate Body Report, US-Softwood Lumber IV (WT/DS257/AB/R, adopted 17 February 2004), para. 59.

62 Indeed, to which element would the prefix 'section' exactly refer? Sections in the HS Nomenclature are subdivided in 'chapters', which are only then subdivided into 'headings'.

63 The 'object and purpose' to preserve subsidies as a development tool might also rather point to a product defined at the section level given that export competitiveness is less easily reached and phasing out is more practicable.

64 On the basis of including intra-EU(27) trade.

65 See also G/SCM/M/79, 3 February 2011, para. 148.

66 G/SCM/M/79, 2 February 2012, para. 166.

67 A final interpretative difficulty is the exact starting point of the eight-year (or two-year in case of small trading countries) extinction period: the moment when export competitiveness was reached (i.e., the end of 2006), or when the computation was made (i.e., March 2010).

68 G/SCM/W/431/Rev.1, 20 March 2001; TN/RL/GEN/136, 16 May 2006.

69 G/SCM/W/431/Rev.1, 20 March 2001, para. 3. 
replaced by a system of moving average. ${ }^{70}$ Second, the fact that the phase-out period has no option for re-inclusion if exports should fall back under the $3.25 \%$ threshold is criticized. ${ }^{71}$ Here, a 'stop-the-clock' mechanism is suggested. ${ }^{72}$ Whereas some developed countries seem to endorse the thrust of these proposals, ${ }^{73}$ many other delegates have voiced their disagreement, with the US apparently taking the most defensive side. ${ }^{74}$ One might assume that developing countries not benefiting from S\&D treatment on export subsidies would likewise not be keen to support more flexibility, certainly because they might compete at a similar level of the product ladder.

\subsubsection{Local content subsidies}

Developing countries are no longer benefiting from S\&D treatment with regard to the prohibition on local content subsidies (Article 3.1(b)) since the transitional period stipulated under Article 27.3 has expired. In principle, flexibility would be anyway less meaningful because Article III:4 GATT and the TRIMs Agreement seem to outlaw these subsidies. ${ }^{75}$ Yet, the TRIMs Agreement still offers limited S\&D treatment on trade-related investment measures, such as local content requirements. ${ }^{76}$ In general, developing countries that have notified their measures inconsistent with the TRIMs Agreement after the entry into force of the WTO Agreement ${ }^{77}$ could uphold these if the transitional period is extended by the Council for Trade in Goods. ${ }^{78}$ Regarding LDCs, the Hong Kong Ministerial Declaration even allowed to maintain existing notified measures that deviate from the TRIMs Agreement, as well as to introduce new measures, to which the Council for Trade in Goods would give 'positive consideration' when notified. ${ }^{79}$ However,

70 Export competitiveness in a certain year would be calculated as an average of the share in exports over the last five years and would be present only if such export shares would pass the 3.25 threshold for two consecutive years. See TN/RL/GEN/136, 16 May 2006.

71 See, for example, G/SCM/W/431/Rev.1, 20 March 2001, para. 4; TN/RL/W/120, 16 June 2003, para. 10.

72 If export competitiveness would be lost during the phase-out period, the clock would be stopped and only re-start after it is reached again. If lost after the phase-out period, export subsidies could be reintroduced until export competitiveness would be established for a second time, in which case a phase-out period of two years would start to run.

73 See, for instance, G/SCM/W/450, 29 May 2001.

74 See, for example, G/SCM/W/443, 17 May 2001; TN/RL/W/254, 21 April 2011, paras. 9-11.

75 But in contrast to the GATT and the TRIMs Agreement, the SCM Agreement does not provide any ground for justification for local content subsidies and has specific and stricter dispute settlement provisions in place.

76 See Article 5 of the TRIMs Agreement (Article 4 is less relevant for our discussion). Regarding disciplines on local content requirements, see Article 2 juncto Annex, para. 1 of the TRIMs Agreement.

77 Or after accession.

78 Article 5.1 juncto 5.3 of the TRIMs. For a list of notifications, see G/L/900, 21 October 2009, Annex I.

79 The text does not explicitly state that these notified new TRIMs have to be approved by the Council for Trade in Goods but only that they have to be given positive consideration. So far, no notifications have 
by virtue of Article 3.1(b) of the SCM Agreement, developing countries are not allowed to make the receipt of a subsidy conditional upon a local content requirement, even if such an investment measure would still benefit from S\&D treatment under the TRIMs Agreement. Indeed, the Panel in Indonesia-Autos concluded that the obligations under the SCM Agreement and TRIMs Agreement apply cumulatively. ${ }^{80}$

\subsection{Special and differential treatment on actionable subsidies}

S\&D treatment on actionable subsidies stipulated in Articles 27.8, 27.9, and 27.13 is in principle available to all 'developing country' Members, which is a selfselected status that could be challenged by other WTO Members. ${ }^{81}$ However, China committed upon accession not to rely on this S\&D treatment. ${ }^{82}$ Since it is likewise excluded from S\&D treatment on prohibited subsidies, China's multilateral disciplines on subsidies correspond to those of developed countries. China only explicitly preserved its right to benefit from S\&D treatment regarding CVDs.

What is the scope of developing countries' S\&D treatment on actionable subsidies? ${ }^{83}$ By virtue of Article 27.9 of the SCM Agreement, not all three forms of adverse effects singled out under Article 5 of the SCM Agreement can be invoked against subsidies offered by developing countries. 'In the usual case', ${ }^{84}$ other Members can only proceed against injury to their domestic industry as well as against nullification or impairment of tariff concessions or other GATT obligations undertaken by the subsidizing developing country. ${ }^{85}$ In essence, this corresponds to the two first types of adverse effects set out under Article 5 of the SCM Agreement (paragraphs (a) and (b)).

Complaints on the basis of serious prejudice (Article 5(c)), which is the broadest form of adverse effects, are less evident and might even be impossible today according to some authors. ${ }^{86}$ To understand this discussion, Articles 27.8 and 27.9

been introduced. The duration of new TRIMs should not exceed five years, renewable subject to review and explicit 'decision' by the Council for Trade in Goods. Hong Kong Ministerial Declaration (WT/MIN(05)/ DEC, 22 December 2005), Annex F.

80 Panel Report, Indonesia-Autos (WT/DS54, 55, 59, 64R, adopted 23 July 1998), paras. 14.4714.55 .

81 Note that there was no disagreement among the parties in Indonesia-Autos that Indonesia was a developing country entitled to S\&D treatment under Article 27.9 of the SCM Agreement. Likewise, all parties in Brazil-Aircraft agreed that Brazil was a developing country within the meaning of the SCM Agreement. See Panel Report, Indonesia-Autos, para. 14.157; Panel Report, Brazil-Aircraft, para. 7.38.

82 See Report of the Working Party Report on the Accession of China (WT/ACC/CHN/49), para. 171. See also G/SCM/M/66, 14 April 2009, paras. 98-99.

83 Article 27.13 regarding privatization programmes has not been relevant in practice.

84 Panel Report, Indonesia-Autos, para. 14.156.

85 Such nullification or impairment has to impede or displace imports of a like product of another Member into the market of the subsidizing developing country Member.

86 Hoda and Ahuja, above n. 59, at 1028, 1058, 1059. 
have to be read together. By virtue of Article 27.8, the presumption of serious prejudice formulated in Article 6.1 could not be invoked against developing countries, but WTO Members can nevertheless demonstrate, by positive evidence, that serious prejudice is caused in those four situations stipulated in Article 6.1.87 Further, Article 27.9 clarifies that other cases of serious prejudice caused by subsidizing developing countries can surely not be challenged. As the presumption in Article 6.1 expired at the end of 1999,88 the S\&D treatment on this presumption articulated in Article 27.8 no longer has legal implications. More important nowadays is, however, the question whether the four situations opening the door to a serious prejudice claim have likewise disappeared as a result of the expiration of Article 6.1. Surprisingly, this issue was left undiscussed by WTO Members at the time the debate on the extension of Article 6.1 was undertaken. The literature has been divided on this question. On the one hand, Hoda and Ahuja hold that the expiration of Article 6.1 implies that action against developing countries on the basis of the four cases of serious prejudice is excluded. Hence, developing countries may not be subject to a claim that their subsidies have caused serious prejudice. ${ }^{89}$ On the other hand, Clarke and Horlick hold that the expiration of the presumption likely did not alter the four cases upon which serious prejudice can be based. ${ }^{90}$ They explain that 'since the presumption of serious prejudice arising in Article 6.1 never applied to developing countries, it could be argued that the definitional aspect of Article 6.1 still applies, in order to raise a serious prejudice complaint against a developing country Member'. ${ }^{91}$ This interpretation would mean that, in addition to injury to the domestic industry and nullification or impairment, adverse effects could still be shown on the basis of 'serious prejudice' if one of the four situations stipulated in Article 6.1 of the SCM Agreement is present. Once a complainant has demonstrated the existence of one of these four types of subsidies, it will subsequently have to advance positive evidence that these subsidies cause serious prejudice by generating the price/volume effects set out in Article 6.3. ${ }^{92}$ Although both interpretations are plausible, I would expect that a Panel confronted with this

87 The four situations are: (a) the total ad valorem subsidization of a product exceeds $5 \%$; (b) the subsidy covers operating losses sustained by an industry; (c) the subsidy covers operating losses sustained by an enterprise, other than one time measures; or (d) direct debt forgiveness.

88 See also Appellate Body, EC-Large Civil Aircraft (WT/DS316/AB/R, adopted 1 June 2011), para. 668 .

89 Hoda and Ahuja, above n. 59, at 1029; Torres, above n. 39, footnote 19.

90 See P. A. Clarke and G. N. Horlick, 'The Agreement on Subsidies and Countervailing Measures', in P. F. J. Macrory, A. E. Appleton, and M. G. Plummer (eds.), The World Trade Organization: Legal, Economic and Political Analysis - Volume I (New York: Springer, 2005), pp. 679-748, at 728-729. Along the same lines, see F. Piérola, 'Article 6 SCMA', in R. Wolfrum, P.-T. Stoll, and M. Koebele (eds.), WTO: Trade Remedies (Heidelberg: Max Planck Institute for Comparative Public Law and International Law, 2008), pp. 498-536, at 509.

91 See Clarke and Horlick, above n. 90, at 728-729.

92 Or a threat of serious prejudice. See Panel Report, Indonesia-Autos, para. 14.169. 
inquiry would foreclose such serious prejudice claim and would rather opt for the restrictive reading of Article 27.9.93

Is this S\&D treatment on actionable subsidies equally available regarding challenges against export subsidies that are not prohibited by virtue of S\&D treatment? According to most authors, this is not the case. ${ }^{94,95}$ Such export subsidies can be challenged on the basis of the actionable subsidy disciplines similarly as with regard to developed countries. This means that 'serious prejudice' can be demonstrated simply on the basis of Article 6.3. Likely, their interpretation is based on the text of Article 27.7, which refers to the remedies for actionable subsidies singled out under Article 7:

The provisions of Article 4 shall not apply to a developing country Member in the case of export subsidies which are in conformity with the provisions of paragraphs 2 through 5. The relevant provisions in such a case shall be those of Article $7 .{ }^{96}$

On the other hand, this provision might be read together with the relevant parts of Article 27.9, which spells out S\&D treatment on actionable subsidies:

Regarding actionable subsidies granted or maintained by a developing country Member other than those referred to in paragraph 1 of Article 6, action may not be authorized or taken under Article 7 unless (nullification or impairment or injury to the domestic industry). ${ }^{97}$

Reading both provisions together, the unsettled query is whether claims against non-prohibited 98 'export subsidies' under Article 7 are limited to those situations spelled under Article 27.9.99,100 Since even export subsidy could be challenged as

93 First, the text of Article 31 refers to the temporary application of ' $(\mathrm{t})$ provisions of paragraph 1 of Article 6 and the provisions of Article 8' (emphasis added). Hence, it not merely refers to the presumption elaborated in Article 6.1 of the SCM Agreement. Second, the text of Article 27.9 refers to 'actionable subsidies ... referred to in paragraph 1 of Article 6' and, therefore, seems dependent upon the existence of this provision. The alternative reading suggested by Horlick and Clarke is possible but would be more difficult to align to the wording of this text. Third, the restrictive interpretation articulated by Hoda and Ahuja would mean that the extinction of Article 6.1 not only relaxed disciplines on domestic subsidies for developed countries (as the presumption of serious prejudice under Article 6.1 collapsed), but likewise for developing countries. This is justified given that the status of Article 6.1 was, at least in political terms, bound to the status of the green light category. In a sense, the collapse of Article 6.1 would thus compensate both developed and developing countries for more restrictive disciplines on green light subsidies. Fourth and finally, a restrictive reading might find contextual support in Article 27.1, which underscores the important role of subsidies in economic development.

94 Hoda and Ahuja, above n. 59, at 1028, 1058, 1059. This also seems the position of M. Benitah, The Law of Subsidies under the GATT/WTO System (The Hague: Kluwer Law International, 2001), 424 pp., at $258-260$, at 39.

95 Remarkably, Brazil seemed to adopt this position before the Panel in Brazil-Aircraft (para. 4.156).

96 Emphasis added.

97 Emphasis added.

98 These are not prohibited by virtue of S\&D treatment.

99 Recall that the 'serious prejudice' claims might no longer be possible today.

100 The Panel in Indonesia-Autos (paras. 8.53, 8.90, footnote 724) cautiously circumvented this issue. 
an actionable subsidy, ${ }^{101}$ one might suggest that the term 'actionable subsidies' in Article 27.9 includes 'export subsidies'. However, the negotiating history rather seems to confirm that claims against export subsidies benefiting from S\&D treatment are likely not constrained by Article 27.9 of the SCM Agreement. ${ }^{102}$ Therefore, it seems probable that, by virtue of Article 27.7, export subsidies benefiting from S\&D treatment are fully actionable under Articles 5 and 6 .

\subsection{Special and differential treatment on countervailing duties (CVDs)}

The S\&D treatment provisions described above do not restrict the use of CVDs against developing countries but merely have an impact on the use of multilateral remedies. Indeed, Members could impose CVDs to offset specific subsidies from developing countries causing injury to their domestic industry. But a novelty of the SCM Agreement is that a higher threshold is set by raising the de minimis standard (Article 27.10). ${ }^{103}$ Such CVD investigations should be terminated if the overall level of subsidies is less than $2 \%$ ad valorem (in contrast to $1 \%$ otherwise by virtue of Article 11.9) $)^{104}$ or if the volume of subsidized imports is less than $4 \%$ of the total imports. Yet, the de minimis volume threshold does not apply if imports from developing countries whose individual shares are less than $4 \%$ collectively account for more than $9 \%$ of total imports. ${ }^{105}$ Similar to the general de minimis subsidy benchmark, this S\&D treatment is only applicable in the original CVD 'investigation' and not in sunset reviews. ${ }^{106}$ In principle, all 'developing countries' benefit from this S\&D treatment when trading partners aim at imposing CVDs on their subsidized imports. Because CVDs are imposed unilaterally, the initial decision to assign the status of 'developing country' is however made by the importing country. For instance, the US does not recognize China and Vietnam as developing countries in its CVD investigations, ${ }^{107}$ which could be challenged by both countries.

101 Appellate Body Report, US-Large Civil Aircraft (WT/DS353/AB/R, adopted 23 March 2012), para. 1253; Panel Report, Korea-Commercial Vessels (WT/DS273/R, adopted 1 April 2005), para. 7.334.

102 First, the corresponding provision under the Subsidies Code referred to 'any subsidy, other than an export subsidy' and the replacement by the term 'actionable subsidies' in Article 27.9 seems to aim at implementing the new traffic light approach (in a confusing manner), rather than at substantively modifying its scope and, therefore, seems not intended to bring 'export subsidies' within the scope of Article 27.9. Second, developing countries signatories already agreed under the Subsidies Code that their export subsidies should not cause serious prejudice and developed countries aimed at strengthening disciplines on developing countries during the Uruguay Round. The opposite reading would deprive the final sentence of Article 27.7 (i.e., '[t] he relevant provisions in such a case shall be those of Article 7') of any substantive meaning.

103 Such S\&D treatment was not foreseen under the Subsidies Code (above n. 15).

104 Article 27.11 provided for a 3\% de minimis threshold for some developing countries, but provision has expired.

105 Article 27.10 of the SCM Agreement.

106 See Appellate Body Report, US-Carbon Steel (WT/DS213/AB/R, adopted 19 December 2002), para. 82 .

107 See A. Gantz, 'Non-Market Economy Status and US Unfair Trade Actions Against Vietnam', Arizona Legal Studies - Discussion Paper (December 2009), 35 pp., at 7. 
Despite this S\&D treatment, the majority of CVD action taken since the birth of the WTO has targeted developing countries' imports. ${ }^{108,109}$ More than one third of all CVD measures imposed to date are installed on imports from India and China. China only recently became subject to CVD actions given its non-market economy status, but already replaced India as the main target of CVD action in 2011. Unsurprisingly, both China and India have introduced proposals aimed at strengthening the procedural disciplines on CVD investigating authorities. ${ }^{110}$ India equally proposed to raise the de minimis threshold but there seems not much support for these proposals. ${ }^{111}$

The existing substantive and detailed procedural requirements to undertake CVD action are not relaxed with regard to developing countries. Obviously, this resource-intensive trade remedy tool is less useful to developing countries and they might equally be more reluctant to employ this politically sensitive remedy targeting foreign government action. ${ }^{112}$ Overall, more than two-thirds of all CVD actions are undertaken by three developed countries, with the US taking the lion's share, followed by the EU and Canada. ${ }^{113}$ Several other WTO Members, including some developing countries, have likewise imposed CVDs but not to a significant extent. China recently started to employ CVDs against the US and EU. ${ }^{114}$

\section{Normative analysis}

\subsection{Introduction: the rationale for offering and disciplining subsidies}

When critically evaluating the regulatory framework sketched out above, the long understood but still often neglected lesson should be recalled that 'policy space' is not something inherently valuable in the sense of being conductive for spurring economic growth or, more broadly, sustainable development. Since the rejection of

108 These figures might be incomplete as they are based on notifications by Members.

109 Developing countries were subject of $61 \%$ of all CVDs measures. See WTO Secretariat, World Trade Report 2009 - Trade Policy Commitments and Contingency Measures (Geneva: WTO Publications, 2009), 171 pp., at 140. See WTO Secretariat statistics based on notifications by WTO Members. Available at: http://www.wto.org/english/tratop_e/scm_e/cvd_init_exp_country_e.pdf. http://www.wto.org/english/ tratop_e/scm_e/cvd_meas_exp_country_e.pdf.

110 TN/RL/GEN/160, 4 December 2009; TN/RL/GEN/161, 4 December 2009; TN/RL/GEN/169, 14 October 2010; TN/RL/GEN/164, 8 April 2010.

111 See TN/RM/W/4, 25 April 2002; TN/RL/W/99, 3 May 2003.

112 The latter could explain why large developing countries employ much more frequently antidumping duties. In case of tariff overhang, countries could respond by raising their applied level of tariffs, but this should be done on an MFN basis.

113 Developed countries account for $86 \%$ of all CVDs measures (World Trade Report 2009, above n. 109, at 140). See also WTO Secretariat statistics based on notifications: http://www.wto.org/english/ tratop_e/scm_e/cvd_init_rep_member_e.pdf. http://www.wto.org/english/tratop_e/scm_e/cvd_meas_rep_ member_e.pdf.

114 The imposition of CVDs on US broiler products is currently challenged by the US before the WTO dispute settlement system (DS427). 
mercantilism centuries ago by the founding fathers of the comparative advantage theory, it is (or should be) common knowledge that curtailing 'policy space' on trade policy might be costly in political terms but beneficial in economic terms.

Regarding policy space on subsidization, it is far from clear why a static welfaremaximizing government would offer a specific subsidy to an industry in a world of perfectly competitive and complete markets. In case this subsidy is provided by a so-called 'small' country (i.e., a country which cannot affect the world price and thus its terms of trade), a welfare loss arises to this country because the increase in producer welfare does not cover the cost to the government, although the welfare of other countries is, by definition, not affected. A production or export subsidy offered by a so-called 'large' country lowers the world price and, therefore, can affect the welfare of third countries. Because it negatively affects its terms of trade, welfare in the subsidizing country deteriorates even more when a subsidy is given by a 'large' country to its export-competing industry. ${ }^{115}$ Overall, the rest of the world is better off in welfare terms resulting from the depressed world price, but net-exporting countries (and all foreign producers) are adversely impacted, whereas net-importing countries (and all foreign consumers) are benefiting. ${ }^{116}$

To understand why countries offer subsidies to industrial products, politicaleconomy considerations should be taken on board or the perfectly competitive and complete markets assumption has to be relaxed. First, political-economy theory shows that governments could be driven by lobbying efforts of special interest groups, rather than welfare concerns, when providing subsidies. Second, if the perfectly competitive and complete markets assumption is relaxed, governments aiming at maximizing welfare might also offer subsidies in order to correct for market failures. ${ }^{117}$ From a normative perspective, both rationales obviously work in opposite directions. Whereas the political-economy rationale suggests that a country would be better off in welfare terms if multilateral disciplines prevent subsidization ('tie-their-own-hands' argument), the market failure rationale may suggest that policy space should be preserved to offer certain subsidies.

Because subsidies could negatively affect the competitive opportunities of foreign producers, GATT/WTO Members have gradually agreed to reduce the risk of

115 A welfare maximizing large country is rather advised to tax exports. A production subsidy to its import-competing industry could, in theory, be welfare-improving for the subsidizing country, but an optimal tariff would be a more direct, and thus an efficient, instrument to exploit its terms of trade.

116 One reason why these subsidies are usually criticized by third countries could be seen in the fact that the adversely affected producers are better organised than benefitting consumers.

117 They could also be used to exploit strategic trade opportunities in oligopolistic markets (i.e., profitshifting rationale), but this is less relevant in the context of developing countries. J. A. Brander and B. J. Spencer, 'Export Subsidies and International Market Share Rivalry', 18 Journal of International Economics (1985), 83-100. The specific assumptions adopted in the Brander - Spencer model also make export or general output subsidies not a robust policy recommendation. See, e.g., J. Eaton and G. M. Grossman, 'Optimal Trade and Industrial Policy under Oligopoly', 101:2 The Quarterly Journal of Economics (May, 1986). 
subsidy wars and restrict their policy space on subsidization. A mixture of differences in trade distortive effect and in justifiability in terms of correcting for market failures explains two bifurcations in the development of multilateral subsidy disciplines. First, the fact that export subsidies are, by their nature, more likely to distort trade than domestic subsidies, and are less often justified on the basis of the market failure rationale, explains why countries have first disciplined export subsidies, and only in a later stage (and to a lesser extent) domestic subsidies. ${ }^{118}$ Second, the fact that only subsidies by large countries hurt foreign producers and that subsidies might be a useful development tool is consistent with the fact that disciplines were first concluded among developed countries and were only later gradually extended to developing countries. ${ }^{119}$ In the following sections, we assess whether the existing disciplines on subsidies leave an appropriate level of policy space to these developing countries.

\subsection{Disciplines on domestic subsidies}

\subsubsection{The prohibition on local content subsidies}

Developing countries enjoyed temporal flexibility on the prohibition on local content subsidies but this S\&D treatment has expired by now. Often, such local content requirements were put in place as a condition to benefit from subsidization in EPZs. The strategy was to attract foreign direct investment (FDI) through subsidization and to ensure, at the same time, that a viable domestic upstream industry would further develop, for example through knowledge spillovers. Whereas the question on whether subsidies should be given to attract FDI seems still open, empirical evidence has shown that restrictive policies such as local content requirements are in general not conductive for spurring economic growth. ${ }^{120}$ Therefore, the prohibition to make subsidies contingent upon local content seems not problematic. Obviously, developing countries could still spur the development of the domestic input industry by subsidizing this industry directly and offer subsidies to attract FDI in the downstream industry. These subsidies would not be prohibited but would be covered under the general disciplines on domestic subsidies, to which we turn in the next section.

\subsubsection{Disciplines on all other types of domestic subsidies and countervailing duties}

Other WTO Members can take multilateral action against subsidization causing injury to their domestic industry as well as against nullification or impairment of

118 See also Appellate Body Report, US-Large Civil Aircraft, para. 1253.

119 Of course, developing countries would be 'large' with regard to the production of those products in which they have a substantive share of total production.

120 See, for instance, T. H. Moran, E. M. Graham, and M. Blomström (eds.), Does Foreign Direct Investment Promote Development? (Washington, DC: Institute for International Economics, 2005). 
tariff concessions or other GATT obligations (Article 27.9). Although no clear answer exists, we tentatively concluded that claims based on 'serious prejudice' would likely not be allowed anymore. This narrow reading of Article 27.9 should, for two reasons, be endorsed from a normative perspective.

First, the market failure rationale holds that the success of outward-oriented development strategies has shown that substantive leeway for subsidization could be important in the presence of market failures impeding economic growth and diversification (e.g., inducing self-discovery, overcoming coordination failures). ${ }^{121}$ Admittedly, even under the broad interpretation of Article 27.9, a substantive part of domestic subsidies aiming at correcting market failures would not be vulnerable to a challenge on the basis of 'serious prejudice' because such challenge would only be allowed for those types of subsidies listed in Article 6.1 of the SCM Agreement. ${ }^{122}$ Regardless of their nature, subsidies exceeding the threshold of $5 \%$ total ad valorem in terms of the cost to the government would be vulnerable to a serious prejudice claim. ${ }^{123}$ The other types of measures listed in Article 6.1 of the SCM Agreement mainly target subsidies to enterprises or industries in difficulties. While one might suggest that these other types of subsidies are generally considered not justified on economic grounds, temporary subsidization of enterprises having a dominant position in an undiversified market might still be warranted. ${ }^{124,125}$

Second, the systemic rationale, as articulated by Bagwell and Staiger, ${ }^{126}$ holds that the supremacy of subsidies over tariffs to correct domestic market failures carries the risk that overly stringent subsidy disciplines would hamper tariff negotiations. Such a 'chilling effect' would be present if developing countries would be reluctant to cut their tariff levels because their potential subsidies could be challenged before the WTO. This would be detrimental from the perspective of both the subsidizing developing country as well as other countries. For instance, a developing country might be resistant to reduce its bound tariff levels if it is aware

121 The empirical evidence (above n. 6) is theoretically underpinned. The standard rationale for the infant industry argument rests on the assumption of a capital market failure for which a production subsidy would at most serve as a second best corrective instrument. Subsidizing 'infant industries' may be beneficial in a second-best fashion when, for instance, (i) learning spills over to other actors in the economy; (ii) information externalities inhibit self-discovery (see below); or (iii) private actors fail to coordinate their complementary actions.

122 Recall that only 'selective' domestic subsidies are disciplined (Article 2) and that such serious prejudice claim would also be dependent on the successful demonstration of trade effects (Article 6.3).

123 See, for example, Panel Report, Indonesia-Autos.

124 Temporary subsidization would slow down the adjustment process in case of congestion in the labor market. The more workers are unemployed at the same time, the less likely that they will find a job. By temporarily protecting jobs, the chances for unemployed workers to find a job increases (congestion is reduced).

125 Policy space for such subsidies might also be relevant from a systemic perspective (see next paragraph).

126 K. Bagwell and R. W. Staiger, 'Will International Rules on Subsidies Disrupt the World Trading System?', The American Economic Review (June, 2006), 877-895. 
that subsidies granted to firms in difficulties would be challengeable. The options given under the restrictive reading of Article 27.9 to formulate a non-violation complaint or a complaint on the basis of injury to the domestic industry (which is the multilateral alternative of unilateral CVDs) would exactly safeguard further tariff negotiations. Indeed, the first instrument would ensure that other WTO Members could effectively benefit from tariff reductions made by the subsidizing developing country, whereas the presence of the latter option could, in theory, make it credible to import-competing industries that bound tariff levels will not be eroded by foreign subsidization.

Importantly, the S\&D treatment on domestic (and export) subsidies does not preclude unilateral CVD action by other WTO Members. Evaluating the potential for such CVD action, the market failure rationale and systemic rationale point in different directions. On the one hand, the market failure rationale suggests that CVD action against corrective subsidization could not be justified as it might target 'fair' subsidization. ${ }^{127}$ The imposition of CVDs is at odds with the explicit recognition in the SCM Agreement that subsidies may play an important development role. ${ }^{128}$ Hence, the deterrence rationale (i.e., CVDs would deter wasteful subsidization) justifying CVD action does not hold. ${ }^{129}$ On the other hand, CVDs could play a useful role to safeguard tariff negotiations because they provide importing countries with an instrument ensuring that their bound tariff levels will not be eroded. Yet, two arguments cast doubt on whether great importance should be attached to this systemic rationale. ${ }^{130}$ Firstly, the large majority of CVDs are imposed by a small group of developed countries upon some industrial products. Given that these countries already have very low levels of bound tariffs on industrial products, restricting the scope for CVD action would likely not significantly hamper further tariff cuts. Secondly, the multilateral option to challenge domestic subsidies when causing injury to an import-competing domestic industry would in principle offer a less trade-distortive alternative, even though the time-consuming multilateral option might not be considered equally effective by import-competing industries. On balance, the value of subsidies as a corrective development tool and the trade-distortive impact of (a threat of) CVD actions, which in practice

127 Because subsidization is welfare improving for net-importing countries, countries have been advised by Krugman to send a thank you note to the foreign country instead of taking CVD action.

128 Article 27.1.

129 The deterrence rationale for CVDs was rejected by proponents of the entitlement theory in the 1980s. C. J. Goetz, L. Granet, and W. F. Schwartz, "The Meaning of "Subsidy" and "Injury" in the Countervailing Duty Law', 6 International Review of Law and Economics (1986), 17-32; R. Diamond, 'Economic Foundations of Countervailing Duty Law', 29 Virginia Journal of International Law (1989), 767-812.

130 CVDs would allow governments to make a credible commitment to their import-competing industries that bound levels will be respected. This would make it more feasible in political-economy terms to agree upon multilateral tariff reductions. See also A. O. Sykes, 'Countervailing Duty Law: An Economic Perspective', 89 Columbia Law Review (March, 1989), 199-262. 
predominantly target developing countries' imports, would justify further increasing the de minimis threshold for taking CVD action against developing countries' imports. ${ }^{131}$

Given that domestic subsidies offered by developing countries still remain countervailable and actionable under some circumstances, the reinstallation of a kind of green light category of domestic subsidies would effectively offer some more policy space to developing countries. Hoekman et al. have formulated such a proposal for the reactivation of the green light status of R\&D subsidies with respect to developing countries. ${ }^{132}$ In particular, flexibility has to be given to tackle information externalities inhibiting self-discovery as explained by Hausmann and Rodrik. ${ }^{133,134}$ To be precise, Hoekman et al.'s reasoning does not assume the mere reactivation of the $R \& D$ subsidies carve-out in its current form stipulated in Article 8 because this only gave leeway to assistance for research aiming at inventing new products (i.e., on-the-frontier innovations). Instead, assistance promoting selfdiscovery aims at supporting firms to discover which existing products could be produced domestically at competitive prices (i.e., inside-the-frontier innovations). They propose increased notification and 'soft' surveillance to prevent private capture and to enhance the credibility of exit mechanisms. ${ }^{135}$ Combining increased policy space with strengthened international surveillance could indeed be useful, but only if the carve-out would equally place subsidization outside the reach of potential CVD action. ${ }^{136}$

\subsection{Disciplines on export subsidies}

\subsubsection{Policy space given to some developing countries to offer export subsidies}

Two broad arguments underpinning the need for policy space to subsidize exports in developing countries have been distinguished. First, evidence that exporting firms are relatively more productive suggests that it might be appropriate to link

131 This has been suggested by India in Doha Round.

132 See TN/RL/41/Rev.1, 10 March 2003.

133 B. M. Hoekman, K. E. Maskus, and K. Saggi, 'Transfer of Technology to Developing Countries: Unilateral and Multilateral Policy Options', IBS Research Program on Political and Economic Change, Working Paper PEC 2004-2003 (May, 2004), 34 pp., at 22-23.

134 Rodrik and Hausmann have explained that the cost of discovering what a country can produce profitable is borne by the initial investor but this has a 'demonstration effect' on others to enter this profitable market without bearing the initial sunk cost. Assuming low barriers to entry, this knowledge spillover implies that market forces lead to underinvestment in self-discovery. R. Hausmann and D. Rodrik, 'Economic Development as Self-Discovery', 72 Journal of Development Economics (2003), 603-633, at 604-605. Empirical support for this market failure hypothesis has been found by B. Klinger and D. Lederman, 'Export Discoveries, Diversification, and Barriers to Entry', 35 Economic Systems (2011), at 64-83.

135 See Hoekman, Maskus, and Saggi, above n. 133, at 22-23.

136 Such self-discovery subsidies should extinguish over time, because only in that situation can it be effectively demonstrated that the products in question can be produced at competitive (i.e., non-subsidized) prices. 
subsidization aimed at overcoming market failures to export performance (i.e., carrot-and-stick rationale), certainly because market failures are often considered relatively more prevalent in the trading sector. Export subsidies could be used to overcome market failures related to, for instance, inducing self-discovery. ${ }^{137}$ Second, the finding of a learning-by-exportation effect, often combined with the assumption that such learning spills over to other segments of the economy, provides an alternative justification for subsidizing exports (i.e., productivity improvement rationale). This exactly explains the plea in a recent World Bank study by Newfarmer et al. for proactive policies in developing countries to support trade and export (diversification) in particular. ${ }^{138}$ This study holds that selective and functional government interventions might be needed to spur export diversification hampered by serious market failures, in which the optimal strategy depends on the specific characteristics of each country ('one size does not fit all'). ${ }^{139}$ Further, developing countries have underscored that such distortions are more prevalent in their markets, and export subsidies would thus merely 'level the playing field' with exporters from more developed countries. ${ }^{140}$

At present, only two groups of developing countries still benefit from S\&D treatment on export subsidies.

First, policy space to offer whatever type of export subsidy is offered to LDCs and those low-income countries listed in Annex VII(b) that have not reached the $\$ 1,000$ threshold. Generally speaking, this differentiation on the basis of income level could be endorsed as the need for S\&D treatment on export subsidies might be grossly related to the level of development. Yet, the exclusion of newly acceded developing countries (as well as - probably-graduated LDCs) with income levels below this threshold clearly fails to honour this principle. The assumption that original WTO developing countries would have 'paid' for their S\&D treatment by making deeper concessions fails since newly acceded developing countries have generally made concessions that are far more extensive. Hence, no justification could be given for their exclusion. A legitimate concern by graduated Annex VII developing countries is that they will have to eliminate export subsidies from the moment of graduation. A transparent and well-defined extinction period would serve the trading interests of their business communities.

137 Although failing to discriminate between innovators and imitators, an export subsidy might be useful to induce self-discovery as it directs innovations at the world market and offers a straightforward criterion to filter out unsuccessful innovations ex post (performance criteria). Hausmann and Rodrik, above n. 134 , at 630 .

138 See Newfarmer, Shaw, and Walkenhorst, above n. 7.

139 See also Commission on Growth and Development, The Growth Report-Strategies for Sustained Growth and Inclusive Development (Washington, DC: The World Bank, 2008), 190 pp., at 11.

140 See, for instance, MTN.GNG/NG10/W/33, 30 November 1989, para. 7; TN/RL/W/99, 6 May 2003. The first-best option would be to correct the market failure directly, which does not involve export subsidization unless, for instance, in case of positive learning-by-exporting externalities. 
Second, some small trading developing counties are allowed to maintain specific programmes related to exemptions to exporters from the payment of import duties and internal taxes, which are often implemented in EPZs. Generally speaking, the installation of EPZs could be considered as an adequate development strategy so as to attract FDI and spur exportation in the first phase of development, though empirical evidence on positive productivity effects of FDI (through for instance knowledge spillovers) is not very strong. ${ }^{141}$ Anyway, these small trading developing countries will have to bring their incentive programmes into conformity with the SCM Agreement as from 2015. This means that rebates offered to exporters will have to be confined to indirect taxes and tariffs on inputs consumed in the production process. ${ }^{142}$

Importantly, this S\&D treatment is constrained in a double way. First, such export subsidies remain actionable and countervailable (Articles 27.7 and 27.10). ${ }^{143}$ The importance of export subsidies as a development tool in some circumstances as well as the need for legal certainty not only calls for raising the threshold to take unilateral CVD action, but likewise suggests that the scope for actionable subsidies claims taken against export subsidies should be limited (Article 27.4). At present, it appears that WTO Members could base such claims on all types of adverse effects singled out under Article 5, whereas it would be appropriate to restrict such potential actions. To temper the risk of subsidy wars and subsidization not based on the market failure rationale, actionable subsidy claims could be allowed as originally crafted under Article 27.9. This would mean that export subsidies could be challenged not only in case injury to other countries' domestic industry is shown, but equally in those four situations stipulated in Article 6.1 (e.g., subsidization above $5 \%$ ad valorem; to cover operating losses) if serious prejudice could be demonstrated. ${ }^{144}$

Second, the right to offer export subsidies also extinguishes in case a developing country has reached export competitiveness in a certain product (Article 27.6). It seems unlikely that small-trading developing countries and LDCs will soon reach the required level of export competitiveness (3.25\% in world trade) in any product. Rather, this extinction might be of more significance to larger export-oriented developing countries listed in Annex VII(b), such as India, Indonesia, the

141 Empirical evidence on horizontal spillovers is mixed but the evidence on positive productivity effects on suppliers (vertical) is somewhat more promising. See, for instance, J. Bitzer and H. Görg, 'Foreign Direct Investment, Competition and Industry Performance', 32:2 The World Economy (2009), 221-233. Because spillovers are hard to calculate, subsidies might easily be offered beyond legitimate levels. See B. S. Javorcik, 'Can Survey Evidence Shed Light on Spillovers from Foreign Direct Investment?', 23:2 The World Bank Research Observer (Fall 2008), 139-159.

142 Alternatively, the export contingency condition attached to incentives implemented in EPZs could be deleted. These schemes would still be vulnerable to actionable subsidy claims and CVD action. See Torres, above n. 39, at 220 .

143 Recall that export subsidies are deemed to be specific.

144 Nullification or impairment of tariff concessions is not relevant with regard to export subsidies. 
Philippines, Egypt, and Pakistan. ${ }^{145}$ Given that a positive determination of India's export competitiveness in textiles has recently been made, it will have to gradually phase out its export subsidies over a period of eight years. Although rather inscribed on request of other WTO Members to safeguard their trading interests, this export competitiveness exception seems to serve as a useful exit mechanism in case export subsidies are no longer strictly needed and when they become sufficiently large to effectively hurt foreign producers. ${ }^{146}$ Indeed, export subsidies seem no longer optimal once the infant industry has grown up. ${ }^{147}$ For example, discovery-encouraging export subsidies to first-movers should only be temporary. Nonetheless, the above-mentioned World Bank study underscored not only the importance of the 'discovery phase' but equally of the 'rapid-growth' or acceleration phase of exports. ${ }^{148}$ Because developing countries' exporters often fail to penetrate new markets (i.e., geographical diversification), graduation on the basis of export competitiveness should not occur too swiftly. This might underpin developing countries' proposals to redefine this concept in a way that export competitiveness is not achieved as a result of short-term market fluctuations and to introduce the stop-the-clock mechanism. At the same time, the usefulness of this exit mechanism should urge WTO Members to solve their disagreements on the interpretation of essential elements revolving around export competitiveness.

The major downside of this policy space on export subsidies (and domestic subsidies) is the risk that governments are captured by producers' interests when allocating subsidies or when deciding on prolonging subsidization in case the initial economic justification no longer holds. Therefore, some authors like Finger and Winters regret such flexibility as it prevents those countries to tie their own hands' ${ }^{149}$ Yet, this inherent risk of any government intervention does, at present, not seem to justify further curtailing this policy flexibility. First, to recall the conclusion of the above-mentioned World Bank study: 'laissez-faire policies combined with low tariffs are rarely sufficient to prompt dynamic export drives or overcome obstacles in other areas'. ${ }^{150}$ The prevalence of market failures combined with the importance of dynamic export drives simply calls for some flexibility on subsidizing exports in low-income developing countries. Second, such an outward-oriented development strategy would generally be less prone to private capture than an import-substitution strategy because the former mostly entails a

145 See Creskoff and Walkenhorst, above n. 32, at 23.

146 See, for example, MTN.GNG/NG10/W/29, 22 November 1989, at 2; MTN.GNG/NG10/W/20, 15 June 1988 , at 7.

147 Other instruments (e.g., domestic subsidies) might become more useful.

148 Newfarmer, Shaw, and Walkenhorst, above n. 7.

149 M. J. Finger and L. A. Winters, 'What Can the WTO Do for Developing Countries?', in A. O. Krueger (ed.), The WTO as an International Organization (Chicago: The University of Chicago Press, 1998), 425 pp., 365-392, at 387.

150 P. Brenton, R. Newfarmer, W. Shaw, and P. Walkenhorts, 'Breaking Into New Markets: Overview', in Newfarmer, Shaw, and Walkenhorst, above n. 7, 1-35, at 27-28. 
cost to the government whereas the latter generates tariff revenue. Third, as a systematic argument, leaving policy space for a more promising outward-oriented development strategy might make these countries also more willing to restrict their policy space to revert to an often detrimental import-substitution development strategy (e.g., accept further tariff bindings). Fourth, these low-income countries' budgetary constraints might de facto prevent governments from overly subsidizing their exporting sector or entering into subsidy wars. Development assistance used to promote the trading sector might equally offer some oversight when based on soft or hard conditionality. Fifth, the fact that these countries are often 'small' in terms of production of the subsidized product implies that these subsidies do, in principle, not substantially hurt foreign producers, and if their share in trade grows to an extent harmful to foreign producers, the twofold constraint on S\&D treatment becomes relevant (i.e., phase out in case of export competiveness and the risk of actionable subsidy or CVD action by trading partners). Sixth, and finally, making such policy space subject to a development needs test under the WTO so as to prevent private capture does not seem a suitable option either. Until 2003, other developing countries were precisely given the right to grant export subsidies insofar these were consistent with their development needs (Article 27.4). Confronted with this test, however, the Panel in Brazil-Aircraft correctly deemed this provision as 'troubling from the perspective of a panel' because it calls for 'an inquiry of a peculiarly economic and political nature' for which the country in question is best placed. ${ }^{151}$

In sum, the limited policy space offered to some low-income developing countries to subsidize their exports should be preserved. At most, a more efficient notification procedure might increase the transparency on such export subsidies, reduce the risk of private capture and subsidy wars. ${ }^{152}$ Yet, explicitly recognising that such subsidies are granted might not be welcomed by these countries as long as they are vulnerable for CVD action by trading partners.

\subsubsection{The prohibition on export subsidies imposed upon other developing countries}

The prohibition on export subsidies is fully enforceable against all other developing countries since 2003. Proponents of 'policy space' have criticized the limitations set under the SCM Agreement upon developing countries' freedom to offer subsidies, whereby they primarily point to this ban on export subsidies. ${ }^{153}$ In their view, those policy constraints would prevent developing countries from adopting the successful development path followed by the East Asian Miracle countries and high-income

151 See Panel Report, Brazil-Aircraft, para. 7.89 (footnotes deleted).

152 Article 25. The TPRM already partly increases this transparency.

153 See, for instance, D. Rodrik, One Economics-Many Recipes-Globalization, Institutions, and Economic Growth (Princeton: Princeton University Press, 2007), 255 pp., at 148-149; UNCTAD, above n. 1 , at 171 . 
countries in their early stages of development. Formulating this argument, Lee has advanced a proposal to lift this ban and to allow developing countries to offer a certain amount of (export) subsidies set in accordance to their development level. ${ }^{154,155}$ This level of so-called 'development-facilitation subsidies' would be exempted from any potential multilateral (i.e., actionable or prohibited subsidy claims) or unilateral (i.e., CVDs) response by other Members and would only be subject to a procedural safeguard so as to prevent abuse. ${ }^{156}$ Yet, Lee offers no details on the thorniest facet raised by his proposal: what amount of subsidies would be allowed for each developing country under such a sliding scale approach? He only puts forward that this 'needs to be further debated with respect to their effect on development'. ${ }^{157}$ Finally, Lee admits that his proposal might generate a detrimental subsidy race, but that this issue should be left to the judgment of the developing country in question. ${ }^{158}$

Considering the success of the East Asian Miracle countries, one cannot but concur that such development strategy might no longer be employed by larger developing countries under the current WTO framework. In its revision of the factors explaining the East Asian success, the World Bank in its East Asian Miracle study explicitly acknowledged the contribution of functional government interventions (i.e., targeting exports in general), though it was still somewhat more skeptical on the importance of selective interventions (i.e., subsidizing certain exporting sectors or industries in particular). ${ }^{159}$ Yet, even functional interventions directly targeting exports in general, like subsidized credits or R\&D subsidies available to all exporters, would likely be captured under the current prohibition on export subsidies as they are either de jure export contingent or, at least, de facto export contingent because they are geared to induce future export performance. ${ }^{160}$ Making general available subsidies conditional upon export performance as part of a carrot-and-stick strategy is thus no longer allowed. Therefore, even if one doubts that selective interventions were important to explain the East Asian miracle, it seems that a similar strategy targeting exports can no longer be put in place by a

154 Y.-S. Lee, 'Facilitating Development in the World Trading System - A Proposal for Development Facilitation Tariff and Development Facilitating Subsidy', 38:6 Journal of World Trade (2004), 935-954, at 948-954.

155 See also Y.-S. Lee, 'Economic Development and the World Trade Organization: Proposal for the Agreement on Development Facilitation and the Council for Trade and Development in the WTO', in T. Chantal and J. Trachtman (eds.), Developing Countries in the WTO Legal System (Oxford: Oxford University Press, 2009), pp. 291-319.

156 Next to notification to the WTO, this would provide for prior public notice as well as public hearings on its implementation.

157 Lee, above n. 154 , at 951.

158 Ibid., at 952-953.

159 See World Bank, The East Asian Miracle, above n. 7.

160 Linking R\&D subsidies to export performance induces firms to export rather than to sell domestically and would thus be contingent upon exportation according to the Appellate Body (see below n. 165). Export subsidies are also deemed to be specific (Article 2.3). 
group of developing countries. At the same time, the proposition that the success of this development strategy would urge a fundamental overhaul of the export subsidy disciplines has to be nuanced for several reasons.

First, more open trade regimes in exporting markets (e.g., lower tariff barriers and a decreased scope for competitive subsidization) suggest that the same level of policy space may not be needed to penetrate export markets. Indeed, it should be recognized that developed countries' policy space for subsidization and CVD action has likewise been constrained since the conclusion of the Uruguay Round. This is a major advantage of the current system for larger developing countries that is often neglected by those authors pleading for more policy space to developing countries. Take, for example, the rivalry between Brazil and Canada in the regional aircraft sector (Embraer versus Bombardier) that was fought out before the WTO. One might criticize the fact that the SCM Agreement precluded Brazil from offering export credit support at subsidized terms to Embraer even when, as the Panel equally acknowledged, this might have been consistent with its development needs. ${ }^{161}$ At the same time, Brazil might never have won a subsidy war against Canada in the regional aircraft sector under the pre-SCM Agreement period. The strengthening of the disciplines upon Canada under the SCM Agreement might have reduced the need for Brazil to offer export subsidies so as to compete in this market. ${ }^{162}$

Second, the tightening of export subsidy disciplines on developing countries that are higher on the development ladder might also be beneficial to lower income developing countries as it facilitates their penetration of new exporting markets. Again, the fact that a group of low-income developing countries still benefits from S\&D treatment on export subsidies is regularly overlooked by proponents calling for more flexibility. For example, in making their claim for export subsidies to induce self-discovery, Hausmann and Rodrik criticize that '(n)ew international agreements in the context of the World Trade Organization have made such subsidies illegal'. ${ }^{163}$ Yet, virtually all countries used as examples to underpin their claim for government interventions inducing self-discovery are still allowed to use export subsidies to this end. ${ }^{164}$ Arguably, the value of their S\&D treatment would

161 Panel Report, Brazil-Aircraft, para. 7.92. Rodrik pointed to the outcome of this case against Brazil as an illustration that the WTO precludes successful development strategies. See Rodrik, above n. 153, at 226 , footnote 13 .

162 Developed countries were already subject to a prohibition on export subsidies under the Subsidies Code. Yet, disciplines on export credit support were far less restrictive and the WTO dispute settlement system also improved the enforceability of this prohibition. Importantly, Brazil was successful in its various counterclaims against Canadian export subsidies.

163 R. Hausmann and D. Rodrik, 'Economic Development as Self-discovery', 72 Journal of Development Economics (2003), 603-633. In other publications, Rodrik recognizes that some countries benefit from an exemption on export subsidies but he often limits this S\&D treatment to LDCs (see, for example, below n. 173).

164 Only one of the listed examples has recently graduated (i.e., Dominican Republic). 
be reduced if developing countries with higher income levels would also be allowed to employ such export subsidies.

Third, domestic rather than trade instruments such as export subsidies become more relevant for developing countries that have reached a certain income level, even though the cut-off point is difficult to define.

For instance, Rodriguez-Clare has argued that countries could in the first stage of development induce self-discovery along the lines suggested by Hausmann and Rodrik and that, once they have 'discovered' their comparative advantage, policies promoting clustering in some sectors should be put in place. ${ }^{165}$ Instead of 'hard' industrial policies such as import substitution or export promotion used in the initial phase, 'soft' industrial policies such as R\&D subsidies, infrastructure investments, or regulatory reforms inducing clustering in some selected sectors should be employed in the next phase of development. ${ }^{166}$ Rodriguez-Clare's suggestion to make a prior selection among all sectors which have shown to be successful in exporting (i.e., in which a country has revealed its comparative advantage) would likely be insufficient to categorize such grants as 'export subsidies' within the meaning of the SCM Agreement, as long as this subsidy is not 'geared to induce the promotion of future export performance by the recipient'. ${ }^{167}$ An export subsidy gives an incentive to export rather than to sell domestically, which is not present if a subsidy is supposed to boost future exports and domestic sales to a similar degree (i.e., does not affect the ratio of exports over domestic sales). ${ }^{168}$ Thus, not all subsidies to an export-oriented firm qualify as an export subsidy. ${ }^{169}$

Even if one considers inducing self-discovery still important in further stages of development, ${ }^{170}$ increased government capabilities might make it no longer needed

165 A. Rodríguez-Clare, Microeconomic Interventions after the Washington Consensus (Washington, DC: Inter-American Development Bank, February 2005), 37 pp., at 23.

166 This would be more transparent and less costly. Rodríguez-Clare, above n. 165, at 28.

167 Appellate Body Report, EC-Large Civil Aircraft, paras. 1044, 1086, 1091, 1098, 1099, 1102.

168 An export subsidy is only present if it is provided so as to incentivize the recipient to export 'in a way that is not simply reflective of the conditions of supply and demand in the domestic and export markets undistorted by the granting of the subsidy'. Appellate Body Report, EC-Large Civil Aircraft, paras. 1045, 1048.

169 Footnote 4 of the SCM Agreement; Appellate Body Report, EC-Large Civil Aircraft, para. 1092. The Appellate Body has also underscored that export orientation of a firm may form ' $a$ relevant factor' but is insufficient on itself. See Appellate Body Report, Canada-Aircraft, para. 173 (emphasis in the original).

170 Referring to the findings by Imbs and Wacziarg, Rodriguez-Clare holds that the appropriate mix of both types of industrial policy depends on the level of development: poor countries should induce selfdiscovery and more advanced countries should induce specialization. However, Imbs and Wacziarg show that countries start specializing relatively late in their development process and specialization of exports even kicks in at a much later stage. The 2009 World Bank study seems to approach both types of interventions in a complementary rather than sequential way. H. Hesse, 'Export Diversification and Economic Growth', in Newfarmer, Shaw, and Walkenhorst, above n. 7, 55-80, at 58; J. Imbs and R. Wacziarg, 'Stages of Diversification', The American Economic Review (March, 2003), 63-86; Newfarmer, Shaw, and Walkenhorst, above n. 7, at 3-4; Rodríguez-Clare, above n. 165, at 23-24. 
to rely upon export performance so as to assess successful discoveries (i.e., carrotand-stick argument). ${ }^{171}$ In general, domestic market failures inhibiting further export diversification might not necessitate subsidies contingent upon exportation in case government capabilities and income levels have improved. ${ }^{172}$ Therefore, policy space for domestic rather than export subsidies might turn out particularly relevant in later stages of development. Once more, the reality that all developing countries are still enjoying more leeway to offer such domestic subsidies under the SCM Agreement seems not always sufficiently understood. ${ }^{173}$

Fourth, exempting export subsidies offered by all developing countries might even have an adverse impact on the dynamic of further tariff negotiations. If, as under Lee's proposal, WTO Members would be precluded from CVD or multilateral action against foreign subsidization, they might become reluctant to make tariff cuts that could be further eroded by such (export) subsidization. ${ }^{174,175}$

For all these reasons, proposals to reinstall substantive leeway to all developing countries on export subsidies might be neither strictly needed nor realistic as they would be opposed by developed as well as low-income developing countries. Yet, the activation of the prohibition on export subsidies with regard to developing countries is problematic insofar this ban is drafted in a way that reflects the interests of developed countries. Firstly, the cost to the government standard on export credit support in the Illustrative List on Export Subsidies is detrimental to exporting developing countries, even though the case law has partly reduced this disequilibrium. ${ }^{176}$ Secondly, the fact that allowance for duty drawback systems is only foreseen for inputs 'consumed in the production of the exported products' equally puts developing countries' exporters at a disadvantage because they face relatively higher tariff levels on capital imports. ${ }^{177}$ Although India's proposal in the Doha Round to allow for rebates on capital goods is considered solid on economic grounds, ${ }^{178}$ developed countries lack any incentive to concur because it would ease

171 Rodrik, for example, proposes to organize bids for public resources on the basis of pre-investment proposals so as to subsidize costs of self-discovery. Rodrik, above n. 153, at 117.

172 The interventions listed by Rodrik as part of a successful industrial policy do not necessitate export subsidies. Rodrik, above n. 153, at 117-119.

173 For instance, Rodrik seems to stress the importance of leeway on domestic subsidization but fails to take into account the S\&D treatment on such subsidies offered under the SCM Agreement. See D. Rodrik, 'Growth After the Crisis', Paper prepared for the Commission on Growth and Development (May, 2009), 42 pp., at 23.

174 Such risk would be higher when green light is offered to export subsidies because of their more direct impact on trade compared to domestic subsidies.

175 Even with the CVD option in place, these countries might prefer substantive tariff overhang to be able to counter foreign subsidization.

176 See D. Coppens, 'How Much Credit for Export Credit Support Under the SCM Agreement?', 12:1 Journal of International Economic Law (2009), 63-113.

177 Allowing drawbacks on capital inputs is precisely one of the measures that developing countries still benefiting from S\&D treatment on export subsidies have implemented as part of their EPZs policy. However, these exemptions could still be challenged as actionable subsidies or be countervailed.

178 Communication from the International Monetary Fund (WT/TF/COH/15, 14 February 2003). 
internal pressure to lower tariffs on capital inputs by developing countries. ${ }^{179}$ Likewise, India's demand to allow for a uniform drawback rate for exporters seems not to be endorsed by most WTO Members either, even though the thrust of this proposal equally seems valid as it lowers the administrative burden upon developing countries to implement such resource-intensive drawback systems. ${ }^{180}$

\section{Conclusion}

The SCM Agreement explicitly recognizes the importance of subsidies for spurring development but equally constrains developing countries' freedom to rely upon this policy instrument and does not foreclose that other WTO Members undertake unilateral CVD action. A group of low-income developing countries is still exempted from the ban on export subsidies, whereas some small trading countries also benefit from a limited exemption until 2015. Economic theory and empirical evidence clearly justify this S\&D treatment but likewise suggest that the exposure of their export subsidies to actionable subsidy claims and CVD action is too unrestrained. Graduation in case of export competiveness could, on the other hand, be useful as an exit mechanism when explicit export promotion is no longer strictly needed and harms other (developing) countries' trade opportunities. All other developing countries are currently subject to the prohibition on export subsidies. Hence, the Illustrative List of Export Subsidies, resulting in essence from the bargain between developed countries over the years, has become fully applicable to these developing countries and should be amended insofar it works against their interests. Obviously, the ban on export subsidies firmly restrains these countries' policy options. Nonetheless, the concern that the SCM Agreement precludes developing countries to duplicate the successful development strategy of East Asian miracle countries has to be nuanced. The prohibition on export subsidies imposed upon other countries at equal or higher development levels implies that similar leeway is not necessarily needed to penetrate export markets. Furthermore, economic research has shown that policy space on domestic rather than export subsidies becomes pivotal for countries that have reached higher stages on the development ladder. Here, the SCM Agreement does offer more policy flexibility, though it has been explained that the exact scope thereof is not fully clear. A narrow interpretation would be justified not only on the basis of the importance of corrective subsidies, but also because it facilitates further tariff concessions. Finally, procedural and substantive disciplines upon unilateral CVD responses by other countries have also been elaborated under the SCM Agreement. In legal terms, the higher de minimis threshold makes it more difficult to impose CVDs against

179 The amendment would place drawbacks on capital inputs outside the reach of actionable subsidy claims and CVD action.

180 Communication from the International Monetary Fund (WT/TF/COH/15, 14 February 2003). 
imports from developing countries. In reality, however, this does not preclude that the large majority of CVD action is taken by developed countries against imports from developing countries. Neither the deterrence justification, nor the systemic justification could validate this asymmetric practice. Hence, further raising the de minimis threshold to initiate such CVD action against developing countries' imports seems defensible.

Returning to Lamy's opening question, the best contribution that the WTO can make in this area is certainly not unconstrained 'policy space', though specific amendments of the existing S\&D treatment would increase legal certainty and economic underpinning. With a paralyzed WTO legislator, some of these sensitive elements might have to be solved by the WTO adjudicator (or remain unresolved). 